\title{
Urotensin II in cardiovascular regulation
}

\author{
Fraser D Russell \\ School of Health and Sport Sciences, \\ Faculty of Science, Health \\ and Education, University \\ of the Sunshine Coast, Sippy Downs, \\ Queensland, Australia
}

\begin{abstract}
Cardiovascular function is modulated by neuronal transmitters, circulating hormones, and factors that are released locally from tissues. Urotensin II (UII) is an 11 amino acid peptide that stimulates its' obligatory G protein coupled urotensin II receptors (UT) to modulate cardiovascular function in humans and in other animal species, and has been implicated in both vasculoprotective and vasculopathic effects. For example, tissue and circulating concentrations of UII have been reported to increase in some studies involving patients with atherosclerosis, heart failure, hypertension, preeclampsia, diabetes, renal disease and liver disease, raising the possibility that the UT receptor system is involved in the development and/or progression of these conditions. Consistent with this hypothesis, administration of UT receptor antagonists to animal models of cardiovascular disease have revealed improvements in cardiovascular remodelling and hemodynamics. However, recent studies have questioned this contributory role of UII in disease, and have instead postulated a protective effect on the cardiovascular system. For example, high concentrations of circulating UII correlated with improved clinical outcomes in patients with renal disease or myocardial infarction. The purpose of this review is to consider the regulation of the cardiovascular system by UII, giving consideration to methodologies for measurement of plasma concentrations, sites of synthesis and triggers for release.
\end{abstract}

Keywords: urotensin II, cardiovascular disease, heart failure, hypertension

\section{Introduction}

Urotensin II (UII) is an 11 amino acid peptide derived from larger 124 and 139 amino acid alternative splicing variants (prepro-UII) (Figure 1) (Coulouarn et al 1998; Ames et al 1999). The cDNA of a distinct gene encoding a 119 amino acid precursor protein was also cloned, and the precursor protein was found to generate a biologically active, 8 amino acid peptide designated urotensin II-related peptide (URP) (Figure 1) (Sugo et al 2003). UII and URP have a homologous Cys-Cys ring structure (CFWKYC), and both peptides bind to, and activate a 389 amino acid Goq-coupled receptor (UT) which shares $75 \%$ sequence homology with the rat UT receptor, GPR14 (Ames et al 1999).

Cardiovascular effects of UII include positive inotropy in human and rat myocardium (Russell et al 2001; Russell and Molenaar 2004; Gong et al 2004), although negative inotropy has been reported in canine cardiomyocytes (Morimoto et al 2002) and in rabbit papillary muscle (Fontes-Sousa et al 2007). UII stimulates vasoconstriction or vasodilation depending on the vascular bed and on the condition of the endothelium (Douglas et al 2004a), and vascular smooth muscle cell proliferation, having synergistic interaction with mildly oxidized low density lipoprotein (Sauzeau et al 2001; Watanabe et al 2006a). Remodeling changes also include cardiomyocyte hypertrophy in the face of elevated expression of UT receptors (Tzanidis et al 2003; Onan et al 2004), and collagen synthesis (Tzanidis et al 2003). The UII/UT receptor-system is expressed widely within the cardiovascular system, and expression is upregulated in human cardiovascular disease states, including congestive heart failure, essential hypertension, coronary artery disease, type II diabetes, and diabetic nephropathy (Zhu et al 2006). The use of recently developed nonpeptide UT receptor antagonists has 


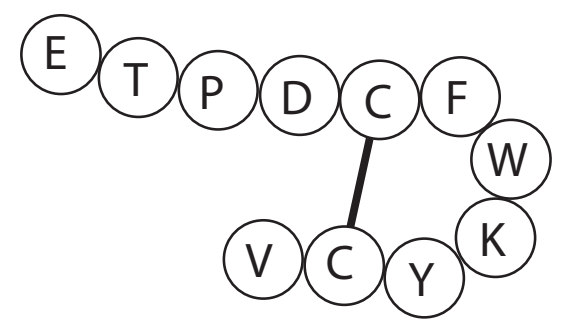

Urotensin II

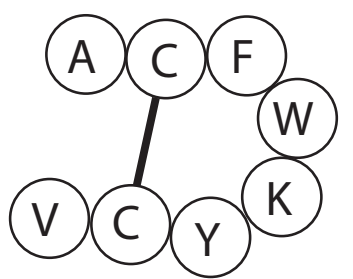

Urotensin II-related peptide

Figure I Amino acid sequence for mature, biologically active human urotensin II (UII) (Coulouarn et al I998; Ames et al I999), and human urotensin II-related peptide (URP) (Sugo et al 2003).

progressed our understanding of the role of UII in the cardiovascular system. Infusion of UT receptor antagonists into animal models of cardiovascular disease has led to improvements in hemodynamics and cardiovascular remodeling, suggesting that UII is involved in the pathogenesis and/or progression of disease.

In contrast to the correlative studies above, plasma UII concentrations were found to be inversely related to markers of sympathetic drive, namely plasma norepinephrine and neuropeptide $\mathrm{Y}$, and heart rate in patients with end-stage renal disease, suggesting that UII may have a protective function under certain circumstances (Mallamaci et al 2005; Zoccali et al 2006). In support of this supposition, plasma UII concentrations were measured and found to be higher in patients with end-stage renal disease who were free of cardiovascular events over a follow-up period of 0.07-5.8 years, compared with patients who experienced one or more cardiovascular events in the follow-up period (Zoccali et al 2006). The authors of this study speculated on a restorative effect of UII on endothelial function, where endothelial dysfunction is characteristic in patients with end-stage renal disease. Consistent with this hypothesis, plasma UII concentrations were inversely correlated with plasma fibrinogen and intracellular adhesion molecule-1, biomarkers of cardiovascular disease and endothelial activation, in patients with end-stage renal disease (Mallamaci et al 2006). Similar inverse correlations of UII concentrations and clinical outcomes were made in patients with acute myocardial infarction. Plasma UII concentrations were raised in patients with an acute myocardial infarction, where patients with levels below the median value fared worse in terms of survival, and adverse clinical outcomes, such as readmission to hospital with heart failure and requirement for urgent revascularization, than patients with concentrations above the median value (Khan et al 2007).

This review examines the role of UII in health and disease, giving consideration to methodologies for UII measurement.
The effects of UII on cardiovascular regulation, and the importance of the endothelium in functional responses to UII will be discussed, as well as sites of synthesis and triggers for its' release. For discussion of the functional role of UII in the various organ systems, readers are directed to previous review articles (Douglas et al 2004a; Russell 2004; McDonald et al 2007).

\section{Evidence implicating urotensin II as an endogenous mediator of cardiovascular disease}

In vivo and in vitro studies suggest that UII has a role in myocardial and vascular remodeling associated with cardiovascular disease. These studies have typically involved administration of exogenous UII to animals to observe changes in cardiac or vascular structure and function, or treatment of cell cultures with UII to observed effects on cell growth and protein production. For example, incubation of cultured neonatal rat cardiac fibroblasts with UII (100 nM, $24 \mathrm{~h}$ ) resulted in a profibrogenic response with increased expression of fibronectin, and $\alpha_{1}$ (I) and $\alpha_{1}$ (III) procollagen mRNA, and stimulation of collagen synthesis (Tzanidis et al 2003). UII did not produce a hypertrophic response in cultured neonatal rat cardiomyocytes, although this was observed in cells that were transfected with recombinant UT receptors, suggesting that expression levels were normally below that required to trigger the cell growth response (Tzanidis et al 2003; Onan et al 2004). Interestingly, rats that were treated with UII $(5 \mu \mathrm{g} / \mathrm{kg}$ intravenously for 1 day and then $1.5 \mu \mathrm{g} / \mathrm{kg}$ subcutaneously twice daily for 6 days) together with the $\beta$-adrenoceptor agonist isoproterenol ( $5 \mathrm{mg} / \mathrm{kg} /$ day for 7 days), showed a greater increase in heart weight to body weight ratio that was consistent with myocardial hypertrophy, than animals treated with isoproterenol only (Zhang et al 2007). Increased expression of UT receptor mRNA was detected in hearts obtained from rats treated with isoproterenol compared to vehicle (Zhang et al 
2007), and this may explain the ability of UII to stimulate the hypertrophic response in these rats. Studies such as the ones described above, that involve exposure of tissues or cells to high concentrations of exogenously administered UII contribute to our understanding of possible pathogenic changes that occur in disease.

Elevated circulating concentrations of UII-like immunoreactivity have been detected in patients with various cardiovascular disease states, including heart failure ( $\mathrm{Ng}$ et al 2002; Richards et al 2002; Russell et al 2003; Lapp et al 2004; Gruson et al 2006), hypertension (Cheung et al 2004; Suguro et al 2007), carotid atherosclerosis (Suguro et al 2007), preeclampsia and eclampsia (Balat et al 2005), renal dysfunction (Totsune et al 2001) and diabetes mellitus (Totsune et al 2003). The elevated plasma concentrations of UII are consistent with local production by cells and subsequent release of UII into the circulation. Indeed, several studies have identified increased expression of UII in tissues in patients with cardiovascular disease. For example, immunoreactive staining for UII was not evident in normal coronary arteries (Hassan et al 2005), but staining was observed in endothelial cells of human atherosclerotic coronary arteries (Maguire et al 2004; Hassan et al 2005). Intense immunoreactive staining was also observed in regions of the plaque containing infiltrating inflammatory cells (Maguire et al 2004; Hassan et al 2005), and this was consistent with changes in mRNA expression determined by in situ hybridization (Hassan et al 2005). While UII was either undetected, or weak immunoreactive staining only was observed within human cardiomyocytes from subjects with nonfailing hearts, immunoreactive staining of greater intensity was detected in cardiomyocytes from patients with end-stage congestive heart failure (Douglas et al 2002). Together these findings indicate upregulation of UII expression by cardiovascular tissues, leading to possible increased release of UII into the circulation, in cardiovascular disease. Until recently, it has been difficult to delineate whether elevated circulating and tissue concentrations of UII are markers of disease only, or whether they are additionally, intrinsically implicated in the pathogenesis of disease.

The production of nonpeptide UT receptor antagonists in recent years has allowed investigators to assess the role of endogenous UII in cardiovascular disease (Watanabe et al 2006b). Prevention of pathological changes associated with elevated UII concentrations after administration of a UT receptor antagonist provides strong evidence for a role of UII in the development and progression of disease. Studies have investigated the ability of the UT receptor antagonist
SB-611812 to attenuate cardiac dysfunction in a rat model of coronary artery ligation (Bousette et al 2006a). SB-611812 is a nonpeptide UT receptor antagonist $\left(\mathrm{pA}_{2}=6.59\right.$ in rat aortic contractile experiments) that has no intrinsic activity at UT receptors (Bousette et al 2006a). In this study, rats underwent 8 week ligation of the left anterior descending coronary artery or sham surgery, and were treated with SB6118128 (30 mg/kg/day) or vehicle for 8 weeks. The animals that were treated with the antagonist exhibited marked reductions in cardiomyocyte hypertrophy and ventricular dilatation, reduced pulmonary edema, and improvements in myocardial function as evidenced by significant reductions in left ventricular end diastolic pressure, right ventricular systolic pressure, and central venous pressure compared to vehicle treated animals (Bousette et al 2006a). In the same coronary artery ligation model, treatment of animals with SB-6118128 caused a reduction in interstitial fibrosis within the noninfarct zone of the left ventricle compared with vehicle-treated animals (Bousette et al 2006b). Together, the studies identify improved cardiac function and attenuated cardiac remodeling in the coronary artery ligation model when UT receptors were blocked, and this correlated with improved survival rates over the 8 week treatment period (Bousette et al 2006a).

In a rat, balloon angioplasty model of restenosis, rats were treated with SB-611812 (30 mg/ $/ \mathrm{kg} /$ day) or vehicle for 28 days to determine the effect of the antagonist on intimal thickening (Rakowski et al 2005). Rats that underwent balloon angioplasty and were treated with the UT receptor antagonist had significantly less intimal thickening than vehicle-treated animals (Rakowski et al 2005), indicating that endogenous UII contributes to the pathogenic effect on blood vessel remodeling. ACT-058362 (palosuran) is a nonpeptide, competitive UT receptor antagonist that binds to two populations of UII binding sites $\left(\mathrm{K}_{\mathrm{D}}=1.9 \mathrm{pM}, 155 \mathrm{pM}\right)$ in $\mathrm{CHO}$ cells expressing human UT receptors (Clozel et al 2004). Interestingly, the same study showed that palosuran produced an apparent noncompetitive antagonism of UIImediated contraction of isolated rat aorta. When palosuran (300 mg/kg/day) or vehicle was administered to a streptozotocin rat model of diabetes, increased glucose tolerance and decreased proteinuria were observed (Clozel et al 2006). Survival rates in the diabetic rats treated for 25 weeks with palosuran were markedly greater than for rats treated with vehicle, and this was attributed to antihyperglycemic effects, attenuation of sympathomimetic effects of UII, and prevention of diabetic nephropathy (Clozel et al 2006). Preliminary studies involving administration of palosuran to healthy 
human subjects have been conducted, and the antagonist was found to be well tolerated and rapidly absorbed (Sidharta et al 2005). The antagonist has now been administered to macroalbuminuric diabetic patients at a dose of $125 \mathrm{mg}$, twice daily for 13.5 days, and results indicate no change in renal hemodynamics and a $24.3 \%$ reduction in urinary albumin excretion (Sidharta et al 2006).

\section{Critical role of the endothelium in vascular effects of UII in health and disease}

$\mathrm{UII}$ is a more potent vasoconstrictor $\left(\mathrm{pEC}_{50} 9.3\right.$ compared with 8.6 in human small coronary arteries; Maguire et al 2004) and a more potent cardiostimulant $\left(\mathrm{pEC}_{50} 9.5\right.$ compared with 8.5 in human atrial trabeculae; Russell et al 2003), than endothelin-1. When UII was infused into the brachial artery of healthy, normotensive, nonsmoking subjects, a dosedependent fall in forearm blood flow was observed (Böhm and Pernow 2002), indicating vasoconstriction. These findings were consistent with in vitro experiments, where it was identified that UII caused potent vasoconstriction in a variety of human isolated blood vessel preparations (Maguire et al $2000,2004)$. The infusion of UII at a rate of $300 \mathrm{pmol} \mathrm{min}^{-1}$ into healthy subjects caused either a reduction in forearm blood flow (Böhm and Pernow 2002), or no change in blood flow (Wilkinson et al 2002), and no change in hemodynamic response (Affolter et al 2002). Possible contributing factors to the divergent findings are patient-to-patient variability with respect to vascular responsiveness to UII (Maguire et al 2000), subject age and possible inclusion of smokers in some of the studies (Affolter et al 2002; Böhm and Pernow 2002; Wilkinson et al 2002). It has been noted that the rate of dissociation of UII from UT receptors is slow, leading to prolonged activation of receptors by UII (Douglas et al 2004b). UT receptors have been shown to undergo rapid sequestration following incubation of HEK293 cells with UII, with trafficking of receptors from the plasma membrane to endosomes (Giebing et al 2005). It has been suggested that as a result of chronic activation and sequestration of UT receptors under normal physiological conditions, the UT receptor system is "functionally silent", and this could explain the above lack of responsiveness of exogenous UII in healthy human subjects (Lambert 2007).

There is strong evidence to indicate that stimulation of UT receptors on animal vascular endothelial cells can trigger the release of nitric oxide and prostaglandins that would serve to balance direct contractile effects of UII on smooth muscle (Bottrill et al 2000; Katano et al 2000; Gray et al 2001; Zhang et al 2003; Ishihata et al 2005; Gardiner et al 2006; Lacza and Busija 2006). For example, studies in newborn pig showed UII-stimulated vasodilation of pial arteries (i.d. 100-120 $\mu \mathrm{m}$ ) that was sensitive to the nitric oxide synthase inhibitor, $\mathrm{N}^{\omega}{ }^{\omega}$-nitro-L-arginine-methyl ester (L-NAME) (Lacza and Busija 2006). In Langendorff-perfused hearts obtained from young (2-3 month old) rats, UII increased coronary flow, and this was inhibited by the nitric oxide synthase inhibitor, $N^{\mathrm{G}}$-nitro-L-arginine and by the cyclooxygenase inhibitor, diclofenac (Ishihata et al 2005), suggesting UII-mediated vasodilation by nitric oxide and prostaglandins. Indeed, this study also revealed that administration of UII to the perfused rat hearts increased concentrations of nitric oxide and the stable metabolite of prostacylin, $\mathrm{PGF}_{1_{\alpha}}$ in the coronary effluent (Ishihata et al 2005). Studies using precontracted rat isolated small mesenteric arteries showed that endothelial-derived hyperpolarizing factor also contributes to the vasorelaxant response of UII (Bottrill et al 2000).

Subject- and regional-variability exists for responsiveness of human blood vessels to UII. Human endothelial-denuded isolated coronary, mammary and radial arteries, and saphenous and umbilical veins contract when exposed to UII (Maguire et al 2000, 2004; Russell et al 2001). UII did not contract human mammary artery or saphenous vein when the endothelium was intact (Hillier et al 2001), suggesting that the endothelial cells release a dilator substance that opposes smooth muscle contraction. In endothelial-intact human small muscular pulmonary arteries, UII produced vasorelaxant responses (Stirrat et al 2001), and in resistance vessels UII produced either a relaxant response (Stirrat et al 2001) or no response (Hillier et al 2001). While the contribution of prostaglandins or endothelial-derived hyperpolarizing factor to relaxation of human blood vessels exposed to UII remains to be determined, it is likely that nitric oxide has a pivotal role. UII did not modulate vascular tone in human isolated pulmonary arteries (i.d. $250 \mu \mathrm{m}$ ), however $3 / 10$ blood vessels contracted when vessels were exposed to UII in the presence of L-NAME (MacLean et al 2000), indicating that a contractile response could be unmasked in some vessels only when nitric oxide production was inhibited. This study using human isolated vessels differs to an in vivo rat study where inhibition of nitric oxide or prostaglandins attenuated the vasorelaxant response to UII, but did not unmask a contractile response (Gardiner et al 2006). In anatomically normal segments of human coronary artery that were removed from patients with coronary atherosclerosis, immunoreactive staining for UII was colocalized with immunoreactive staining for endothelial nitric oxide synthase in the endothelial cells 
(Hassan et al 2005), indicating possible local dilator effects of UII. UII binding sites have previously been localized to vascular endothelial cells (Douglas et al 2002), and it is therefore likely that UII stimulates nitric oxide-dependent vascular relaxation in an autocrine or paracrine manner to oppose contractile effects of UII on smooth muscle.

Recent evidence suggests that endothelial function may be a key determinant of changes in vasomotor tone to UII in vivo. UII was administered by iontophoresis to forearm skin microvessels in healthy subjects and in patients with chronic heart failure, and blood flow in these vessels was measured using laser Doppler velocimetry (Lim et al 2004). In healthy subjects, UII caused an increase in blood flow indicating vasorelaxation, while in patients with heart failure UII caused a decrease in blood flow, indicating vasoconstriction (Lim et al 2004). The differences are attributed to impaired endothelial function in patients with heart failure, where endothelial cells normally produce nitric oxide and prostacyclin which contribute to reduced vascular tone. Loss or dysfunction of the endothelial cells may therefore result in an imbalance in vascular responsiveness to UII, favoring the contractile response over the relaxant response. This hypothesis is supported by a nonsignificant trend for reduced vasodilator response to the endothelium-dependent agonist, acetylcholine, but no diminution in response to the endothelium-independent dilator, sodium nitroprusside in the heart failure cohort (Lim et al 2004). A similar study using iontophoresis compared blood flow in the microcirculation of normotensive subjects and hypertensive patients, where a vasodilator response to UII was observed in the microvessels of normotensive subjects while patients with hypertension responded with a vasoconstrictor response (Sondermeijer et al 2005). Endothelial cell dysfunction is known to be associated with hypertension, as evidenced by diminished acetylcholine-induced relaxation of norepinephrine pre-constricted small subcutaneous arteries (Wang et al 2003). Despite this observation, acetylcholine and sodium nitroprusside produced similar vasodilator responses in the iontophoresis study (Sondermeijer et al 2005), suggesting that only very subtle loss of endothelial function may be required to generate marked differences in vascular tone in hypertensive patients, if indeed endothelial dysfunction is responsible for the observed contrasting responses to UII in these patients.

\section{Considerations for measurement of UII}

Patients with cardiovascular disease are often at risk of development of multiple complications, where for example patients with peripheral arterial disease have an increased risk for development of coronary artery disease and diabetes mellitus. It is therefore imperative that cohorts of patients are well characterized with respect to their condition in order to avoid possible confounding influences on the measurement of plasma UII concentrations. In comparing UII concentrations in patients with hypertension with normotensive controls, Suguro and colleagues (2007) excluded patients who had co-existing disease known to be associated with raised UII concentrations, including coronary artery disease, heart failure, diabetes mellitus or renal dysfunction. UII concentrations were elevated in the hypertensive group $(7.9 \pm 7.6 \mathrm{ng} / \mathrm{ml}$ versus $2.3 \pm 1.2 \mathrm{ng} / \mathrm{ml} ; \mathrm{P}<0.0001)$, representing a 3.4-fold increase. Through careful selection of inclusion and exclusion criteria, these authors were able to attribute the elevation of UII to hypertension, differentiating other disease states that have been reported to increase blood UII concentrations.

UII concentrations have been determined in a variety of pathophysiological conditions, comparing values with nondisease control subjects, and considerable discrepancies have been noted in absolute levels of UII detected. Concentrations of UII-like immunoreactivity in control subjects who have no evidence of heart failure range from $0.8 \mathrm{pg} / \mathrm{ml}$ (Gruson et al 2006) to $3290 \mathrm{pg} / \mathrm{ml}$ (Krüger et al 2005), and in heart failure patients, from $1.5 \mathrm{pg} / \mathrm{ml}$ (Gruson et al 2006) to $6631 \mathrm{pg} / \mathrm{ml}$ (Lapp et al 2004). The differences between studies is marked (over 4,000-fold for both control and heart failure subjects), and possible explanations for these discrepancies are stated below. However, the notion that UII concentrations are elevated in patients with heart failure is not universally accepted. For example, some studies reported increased plasma UII-like immunoreactivity in heart failure patients compared to patients with nonfailing hearts, or in the studies by Lapp et al 2004, compared with subjects classified as New York Heart Association (NYHA) I, by between 1.5 and 10-fold (Ng et al 2002; Richards et al 2002; Russell et al 2003; Lapp et al 2004; Gruson et al 2006), while other studies found no difference in concentrations between control and heart failure patients (Dschietzig et al 2002; Krüger et al 2005). Furthermore, studies that identified elevated UII-like immunoreactivity showed either a correlation (Lapp et al 2004; Gruson et al 2006) or no correlation in concentrations of UII-like immunoreactivity with severity of disease as determined by NYHA class ( Ng et al 2002; Russell et al 2003).

A number of methodological approaches have been used to identify plasma UII concentrations, including the 
use of radioimmunoassay, enzyme immunoassays, and immunoluminometric assays from different commercial and in-house sources, and this may in part contribute to the discrepancies observed. For example, the comparative measurement of plasma UII concentrations in cigarette smokers versus nonsmokers was quite different depending on the type of assay that was employed. Significant increases in UII concentrations were identified when a commercially available radioimmunoassay kit was used $(2.62 \mathrm{pg} / \mathrm{ml}$ for smokers versus $1.67 \mathrm{pg} / \mathrm{ml}$ for nonsmokers; median values, $\mathrm{P}=0.034$ ), but no difference was detected using an immunoluminometric assay (Gold et al 2007). Sensitivity of detection was not the reason for the discrepancy, as the immunoluminometric assay detected UII at 2.4-fold lower concentrations than the radioimmunoassay (Gold et al 2007). Antibodies raised against UII and that recognize the $\mathrm{C}$-terminal hexapeptide amino acid sequence (CFWKYC) do not differentiate UII and URP. A reason for discrepant findings between studies that employ different immunoreactive methodologies might therefore be attributed to differing concentrations of UII, precursor forms of UII, URP, and other unrelated immunoreactive peptides. To underline this point, multiple molecules containing UII-like immunoreactivity have been detected in plasma samples from heart failure patients (Russell et al 2003), and in culture media of adrenocortical carcinoma cells (Takahashi et al 2001).

Verification of peptide identity is possible with analytical instruments such as high performance liquid chromatography which can be used to measure peptide retention times, and mass spectrometry which provide mass-to-charge ratios as a "signature" of the peptide of interest. These technologies were used to differentiate a 25 amino acid C-terminal fragment of pro-UII from the mature, 11 amino acid peptide (Russell et al 2004). Techniques dependent on immunoreactive discrimination are unlikely to distinguish the precursor and mature forms of UII where, for example, the antibody raised against UII exhibited $29 \%$ cross-reactivity with the C-terminal fragment of pro-UII (Russell et al 2003). Plasma concentrations of UII-like immunoreactivity were found to be elevated in patients with heart failure, although mature UII was not identified in the fractions using HPLC-mass spectrometry (Russell et al 2003). These findings suggest increased expression of prepro-UII, prepro-URP, or proteolytic cleavage fragments of the precursor peptides that retain the epitopes required for antibody recognition. The physiological or pathophysiological significance of pro-UII fragments may be dependent on the enzymatic conversion of the fragment to mature UII by the previously characterized urotensin-converting enzyme (Russell et al 2004). Consistent with this hypothesis, the 25 amino acid C-terminal fragment of pro-UII had much reduced potency compared with mature UII for cardiostimulatory effects in isolated human right atrial trabeculae (Russell et al 2003).

The inability to use antibodies to distinguish UII from precursor forms of UII, and in some instances URP, raises questions over the physiological and/or pathophysiological relevance of observed regulatory changes in UII-like immunoreactivity. To address this issue, studies were carried out to detect plasma levels of molecules that have affinity for UT receptors, and that therefore infer biological activity (Aiyar et al 2004). Factors in blood and urine were examined for their ability to compete with [ $\left.{ }^{125} \mathrm{I}\right]-\mathrm{UII}$ for binding to monkey UT receptors that were expressed in HEK-293 cells. The advantage of this approach was that there was no presumption that the competing ligand should exhibit the epitope for recognition by UII antibodies. In urine samples, three HPLC peaks exhibited competitive binding of compounds for [ $\left.{ }^{125} \mathrm{I}\right]$-UII at UT receptors, although only two peaks exhibited UII-like immunoreactive compounds by radioimmunoassay. One of these peaks was consistent with the presence of mature UII, and the other with an immunoreactive species that was not mature UII, 4-11, 5-11 or 5-10 analogues of UII, or URP. Whether this peak contained the same immunoreactive species identified in heart failure patients (Russell et al 2003), is not known. The detection of immunoreactivity that is distinct from mature UII may account for the large discrepancies in absolute concentrations of UII-like compounds between studies (Aiyar et al 2004). A number of studies, including manufacturers of radioimmunoassay kits, have shown no detectable cross reactivity of antibodies directed against UII to endothelin-1, big endothelin-1, somatostatin, angiotensin II, PAMP-20, bradykinin, $\alpha$-atrial natriuretic peptide, calcitonin gene related peptide, adrenomedullin, or norepinephrine (Phoenix Pharmaceuticals, Burlingame, CA, USA; Lapp et al 2004; Russell et al 2003; Aiyar et al 2004; Charles et al 2005), suggesting that these molecules do not contribute to the reported discrepancies in results obtained from studies using immunoreactive techniques. The third peak that did not contain UII-like immunoreactivity but exhibited binding in the competition binding assay (Aiyar et al 2004) suggests the presence of compounds that have affinity for UT receptors, but do not contain the obligatory amino acid sequence of mature UII. Functional assays would be required to determine whether receptor binding observed for these compounds also results in receptor activation. If the unrelated compounds that bind to UT receptors are indeed 
found to stimulate UT receptors, then studies based on measurement of UII-like immunoreactivity alone may considerably under-estimate the significance of the UT receptor system to cardiovascular function, and possibly the extent to which the UT receptor system is regulated in a variety of pathophysiological conditions.

\section{What is the source of UII?}

Low plasma concentrations of UII in healthy subjects have been consistently reported, suggesting that UII does not serve as a circulating hormone under normal circumstances. Plasma concentrations of UII have been shown in many studies to be elevated in cardiovascular disease, notwithstanding the considerations for measurement of plasma UII mentioned above. Interestingly, several studies reported a lack of correlation between plasma UII concentration and severity of disease ( $\mathrm{Ng}$ et al 2002; Russell et al 2003), leading Maguire and colleagues (2004) to speculate on the possible spill-over of excessive local production of UII by tissues into the circulation. The spill-over phenomenon has been reported for other peptide systems, with evidence for polarized release of endothelin-1 from endothelial cells toward the medial vascular smooth muscle cells (Yoshimoto et al 1991; Wagner et al 1992) and the spill over of endothelin-1 in the pulmonary circulation of patients with congestive heart failure (Tsutamoto et al 1994). Studies have identified endothelial cells as a source of UII, with expression of prepro-UII mRNA in cultured human coronary artery and umbilical vein endothelial cells (Totsune et al 2003). Inflammatory cells are also a likely source of UII, with high levels of prepro-UII mRNA expression detected in lymphocytes, with between 8-48-fold lower levels detected in monocytes, macrophages and foam cells (Bousette et al 2004). Positive immunoreactive staining for UII was also detected in inflammatory cells within atherosclerotic lesions of human aorta and in aortae from patients undergoing repair surgery for abdominal aortic aneurysm (Bousette et al 2004), and in atherosclerotic lesions of human coronary artery (Maguire et al 2004; Hassan et al 2005). Expression of UT receptors in lymphocytes was about 20 -fold lower than in monocytes and about 13 -fold lower than in macrophages (Bousette et al 2004), raising the possibility that UII mediates inflammatory cell responses in an autocrine and/or paracrine manner.

The increase in circulating UII in cardiovascular disease may be attributed in part to increased synthesis and release by tissues, or decreased clearance of the peptide. The net production of UII within tissues can be gauged by sampling blood in vascular beds on either side of the tissue and then measuring UII concentrations (Table 1). In patients with congestive heart failure, plasma UII concentrations were higher in the aortic root than in the pulmonary artery (Russell et al 2003), suggesting that UII was being produced in the heart or lungs

Table I Concentration gradients for plasma UII across organ systems. Elevated plasma UII concentrations across tissues is indicative of a site of synthesis and release of UII

\begin{tabular}{|c|c|c|c|c|}
\hline Site of production & Sample site & Plasma [UII] & $P$ value & Reference (Disease/disease model) \\
\hline \multirow[t]{2}{*}{ Heart and lungs } & PA & $38 \pm 6 \mathrm{pg} / \mathrm{ml}$ & $\mathrm{P}<0.00 \mathrm{I}$ & Russell et al 2003 (Congestive heart failure; Human) \\
\hline & AR & $23 \mathrm{I} \pm 69 \mathrm{pg} / \mathrm{ml}$ & & \\
\hline \multirow[t]{2}{*}{ Heart and lungs } & PA & $33 \pm 5 \mathrm{pg} / \mathrm{ml}$ & $P<0.05$ & Russell et al 2003 (Ischemic cardiomyopathy; Human) \\
\hline & $A R$ & $309 \pm 124 \mathrm{pg} / \mathrm{ml}$ & & \\
\hline \multirow[t]{2}{*}{ Heart and lungs } & PA & $130 \pm 32 \mathrm{pg} / \mathrm{ml}$ & NS & Dschietzig et al 2002 (Severe congestive \\
\hline & $\mathrm{LV}$ & $126 \pm 32 \mathrm{pg} / \mathrm{ml}$ & & heart failure; Human) \\
\hline Coronary & LV & $126 \pm 32 \mathrm{pg} / \mathrm{ml}$ & NS & Dschietzig et al 2002 (Severe \\
\hline vasculature/Heart & CS & $\mathrm{ll} 0 \pm 40 \mathrm{pg} / \mathrm{ml}$ & & congestive heart failure; Human) \\
\hline Coronary & $\mathrm{CA}$ & $\mathrm{I} .3 \pm 0.2 \mathrm{pmol} / \mathrm{l}$ & $\mathrm{P}<0.00 \mathrm{I}$ & Charles et al 2005 (Right ventricular pacing model \\
\hline vasculature/heart & CS & $2.1 \pm 0.2 \mathrm{pmol} / \mathrm{l}$ & & of heart failure; Sheep) \\
\hline \multirow[t]{2}{*}{ Liver } & HPV & $11.2 \mathrm{ng} / \mathrm{ml}$ & $\mathrm{P}<0.005$ & Heller et al 2002 (Cirrhosis with ascites; Human) \\
\hline & $\mathrm{HV}$ & $13.9 \mathrm{ng} / \mathrm{ml}$ & & \\
\hline \multirow[t]{2}{*}{ Kidneys } & RA & $1.8 \pm 0.2 \mathrm{pmol} / \mathrm{l}$ & $\mathrm{P}<0.05$ & Charles et al 2005 (Right ventricular pacing \\
\hline & RV & $2.3 \pm 0.2 \mathrm{pmol} / \mathrm{l}$ & & model of heart failure; Sheep) \\
\hline \multirow[t]{2}{*}{ Lower limbs } & FA & $78 \pm \mathrm{II} \mathrm{pg} / \mathrm{ml}$ & NS & Russell et al 2003 (Congestive heart failure; Human) \\
\hline & $\mathrm{FV}$ & $55 \pm 7 \mathrm{pg} / \mathrm{ml}$ & & \\
\hline \multirow[t]{2}{*}{ Lower limbs } & FA & $1.7 \pm 0.2 \mathrm{pmol} / \mathrm{l}$ & NS & Charles et al 2005 (Right ventricular pacing \\
\hline & $\mathrm{FV}$ & $\mathrm{I} .8 \pm 0.2 \mathrm{pmol} / \mathrm{l}$ & & model of heart failure; Sheep) \\
\hline
\end{tabular}

Notes: Concentrations of UII were determined from tabulated and graphical representations of data in the cited references.

Abbreviations: UII, urotensin II; PA, pulmonary artery; AR, aortic root; LV, left ventricle; CS, coronary sinus; CA, carotid artery; HPV, hepatic portal vein; HV, hepatic vein; RA, renal artery; RV, renal vein; FA, femoral artery; FV, femoral vein; NS, not significant. 
or both heart and lungs. In that study, a cardiopulmonary gradient was detected in patients with ischemic cardiomyopathy, with a nonsignificant trend for a gradient in patients with nonischemic cardiomyopathy. Possible synthesis and release of UII from the heart into the circulation was investigated by measuring UII concentrations across the heart using an anaesthetised sheep model (Charles et al 2005). Plasma UII concentrations were higher in the carotid artery than the coronary sinus, where the arteriovenous gradient suggested that the myocardium or coronary vasculature may indeed be a site of UII production and secretion. Immunohistochemical studies in human heart revealed higher expression levels of UII-like immunoreactive staining in the subendocardium than in the mid-myocardium or subepicardium of patients with congestive heart failure (Douglas et al 2002), suggesting that the subepicardium is a source of UII. Together, these findings do not exclude synthesis of UII in the pulmonary tissues, but point to possible production within the subendocardium and release into the heart chambers.

Other sites of UII production include the liver and the kidneys. Samples of blood were taken across the liver in patients with chronic liver disease and UII concentrations were determined. The findings revealed higher concentrations of UII in the hepatic vein than in the hepatic portal vein (Heller et al 2002). More recently, UII concentrations were determined in blood from the femoral and hepatic veins in patients with chronic liver disease, and were found to be higher in the femoral vein (Kemp et al 2007). Together these findings suggest that the liver is a source of UII production in patients with chronic liver disease but that extra-hepatic sites may also contribute to the raised plasma concentrations. The nature of these other sites is not clear, but it is speculated that it may involve the cardiovascular system since widespread circulatory changes (altered mean arterial pressure) were also noted (Kemp et al 2007). The kidneys are an important site for UII production, with evidence for moderate (Coulouarn et al 1998) to high levels of human prepro-UII mRNA expression (Nothacker et al 1999) in this organ. Expression of human prepro-UII mRNA is regulated, with negligible levels detected in fetal kidney (Coulouarn et al 1998; Nothacker et al 1999). In the normal human kidney, high levels of UIIlike immunoreactivity were identified in epithelial cells of the distal convoluted tubules, collecting tubules, collecting ducts and proximal convoluted tubules (Shenouda et al 2002). UII concentrations were found to be elevated in urine from patients with renal tubular disorders compared with controls, indicating increased synthesis and secretion from renal epithelial cells, decreased reabsorption or a combination of both
(Matsushita et al 2001). In some individuals, urinary clearance of UII exceeded glomerular filtration rate (Matsushita et al 2001), indicating that renal tubules are a source of secreted UII. In support of the renal epithelium as a site of synthesis, UII was detected in the culture perfusate of LLCPK1 porcine renal epithelial cells (Matsushita et al 2001). Elevated preproUII mRNA expression was detected in renal biopsies obtained from patients with diabetic nephropathy compared to control nephrectomy samples. The source of this increased expression is likely to be the epithelium, as this tissue showed intense UII-like immunoreactivity (Langham et al 2004). UII-like immunoreactive staining has been reported in renal capillary endothelial cells from control subjects (Shenouda et al 2002), and these cells may be a potential source of increased circulating concentrations of UII detected in patients with renal dysfunction (Totsune et al 2001). It is interesting to note that there was a trend for increased plasma UII concentrations in two patients who had undergone previous (6 months since removal of tissue) bilateral nephrectomy compared to 29 patients undergoing hemodialysis for end-stage renal disease (Mosenkis et al 2007), underlining the importance of nonrenal tissues as additional sources of UII.

\section{What is the stimulus for UII release?}

Plasma concentrations of UII in the aortic root of patients with nonfailing hearts are low, but significantly elevated in heart failure, suggesting that heart failure triggers the increased production of UII (Russell et al 2003). Myocardial necrosis occurs in ischemic cardiomyopathy, a condition associated with the cardiopulmonary gradient of UII mentioned above, and it is possible that this is a stimulus for the release of UII into the circulation. Necrosis can be identified by assessment of morphological changes in the heart, and by elevated concentrations of biochemical markers in the blood, including Troponin $\mathrm{T}$ and creatinine kinase (Alpert et al 2000). However, in a study that examined UII concentrations in patients with acute coronary syndrome, defined as angina lasting more than $20 \mathrm{~min}$ together with additional evidence of cardiovascular disease (Joyal et al 2006), no correlation was observed between concentrations of plasma UII and troponin T (Joyal et al 2006).

Plasma UII concentrations have been shown to increase with increased pressure load, raising the possibility that blood pressure is a stimulus for UII release. For example, plasma UII concentrations correlated positively with increased systolic (Cheung et al 2004; Suguro et al 2007) and diastolic blood pressure in patients with hypertension (Cheung et al 2004), with mean arterial blood pressure in patients with preeclampsia 
and eclampsia (Balat et al 2005), with wedged hepatic venous pressure gradient, which is an index of portal pressure, in patients with portal hypertension (Heller et al 2002), and with increased left ventricular end diastolic pressure in patients with ischemic cardiomyopathy (Lapp et al 2004). Concentrations of UII in the cerebrospinal fluid of hypertensive patients also correlated positively with mean arterial blood pressure (Thompson et al 2003). As indicated above, studies using UT receptor antagonists will be instrumental in differentiating UII as a marker of disease and UII as a contributor to the pathogenesis or progression of disease (Watanabe et al 2006b). It is of interest therefore that gene deletion of UT receptors in mice produced no change in mean arterial blood pressure compared to control mice (Behm et al 2003). UII caused only a small contractile response in aortae from control mice $(17 \%$ of $60 \mathrm{mM} \mathrm{KCl}$ ) and no response in aortae from UT receptor knockout mice (Behm et al 2003). It is thus possible that the failure to detect an altered pressure response in the knockout mouse model is attributed to the low contractile efficacy of UII in the vascular tissue of this species.

Not all studies showed a positive correlation between blood pressure and UII concentrations. For example, a negative correlation was observed between plasma UII concentrations and mean arterial pressure in patients with acute coronary syndrome and stable coronary artery disease (Joyal et al 2006). In contrast to the positive correlations between pressure and UII concentrations described above, Dschietzig and colleagues (2001) showed that neither shear stress nor perfusion pressure were stimuli for UII production in cultures of bovine pulmonary artery endothelial cells. These investigators used a specially designed flow chamber that was capable of adjusting shear stress and perfusion pressure independently, and they found that both prepro-UII mRNA expression and UII secretion decreased in the endothelial cells with increasing perfusion pressure. The effect of perfusion pressure on the UII system identified in this study was different to that on the endothelin system where increased pressure stimulated increased prepro-endothelin-1 mRNA expression from bovine pulmonary artery endothelial cells (Dschietzig et al 2001) and increased secretion of endothelin-1 from human umbilical vein endothelial cells (Hishikawa et al 1995). If UII release is triggered by elevated blood pressure, then UII concentrations would be expected to be lower in hypertensive patients whose blood pressure is controlled by antihypertensive medication compared with untreated hypertensive patients. Cheung and colleagues (2004) observed no difference in UII concentrations for 37 patients with essential hypertension who were treated with antihypertensive medication compared to
25 untreated patients with essential hypertension, although blood pressure was not reported for the treated and untreated cohorts. Although UII concentrations were significantly lower in 72 patients with end-stage renal disease being treated with antihypertensive medication compared to 119 patients with end-stage renal disease who did not receive antihypertensive medication (Mallamaci et al 2006), blood pressures in each cohort were also not reported. It is thus not known whether reduced blood pressure or an effect of antihypertensive medication contributed to the decrease in UII concentrations. Whatever the stimulus for release of UII, it is likely that the chronic nature of disease is paramount in raising blood concentrations. For example, there was no increase in UII concentrations in an acute (7 day) right ventricular pacing model of heart failure compared to nonpaced control animals (Charles et al 2005), but an increase was detected by the same laboratory in patients with chronic heart failure (Richards et al 2002).

\section{Conclusion}

UII has pleiotropic effects within the cardiovascular system, with evidence for modulation of cardiac contractility, vascular tone, cell proliferation, and cell growth. Recent studies have suggested that UII may have a protective effect on the cardiovascular system, while others implicate UII as a harmful mediator. Evidence suggests that the condition of the vascular endothelium is a key determinant in how the cardiovascular system responds to UII. UII and UT receptors are upregulated in a number of cardiovascular disease states, implicating the UT receptor system in the pathogenesis and progression of disease. Nonpeptide UT receptor antagonists have been developed, and their use in animal models of disease point to promising therapies for the future. Enthusiasm for this strategy is underlined by the significant reduction in urinary albumin excretion that was achieved in macroalbuminuric diabetic patients who were treated with the UT receptor antagonist, palosuran. Further investigation of UT receptor antagonists and their efficacy in the treatment of various human cardiovascular disease states in which UII is implicated is warranted.

\section{References}

Affolter JT, Newby DE, Wilkinson IB, et al. 2002. No effect on central or peripheral blood pressure of systemic urotensin II infusion in humans. Br J Clin Pharmacol, 54:617-21.

Aiyar N, Guida B, Ao Z, et al. 2004. Differential levels of "urotensin-IIlike" activity determined by radio-receptor and radioimmuno-assays. Peptides, 25:1339-47.

Alpert JS, Antman E, Apple F, et al. 2000. Myocardial infarction redefined a consensus document of the Joint European Society of Cardiology/ American College of Cardiology Committee or the Redefinition of Myocardial Infarction. J Am Coll Cardiol, 36:959-69. 
Ames RS, Sarau HM, Chambers JK, et al. 1999. Human urotensin-II is a potent vasoconstrictor and agonist for the orphan receptor GPR14. Nature, 401:282-6.

Balat O, Aksoy F, Kutlar I, et al. 2005. Increased plasma levels of urotensinII in preeclampsia-eclampsia: a new mediator in pathogenesis? Eur $J$ Obstet Gynecol Reprod Biol, 120:33-8.

Behm DJ, Harrison SM, Ao Z, et al. 2003. Deletion of the UT receptor gene results in the selective loss of urotensin-II contractile activity in aortae isolated from UT receptor knockout mice. Br J Pharmacol, 139:464-72.

Böhm F, Pernow J. 2002. Urotensin II evokes potent vasoconstriction in humans in vivo. Br J Pharmacol, 135:25-7.

Bottrill FE, Douglas SA, Hiley CR, et al. 2000. Human urotensin-II is an endothelium-dependent vasodilator in rat small arteries. Br J Pharmacol, 130:1865-70.

Bousette N, Hu F, Ohlstein EH, et al. 2006a. Urotensin-II blockade with SB-611812 attenuates cardiac dysfunction in a rat model of coronary artery ligation. J Mol Cell Cardiol, 41:285-95.

Bousette N, Patel L, Douglas SA, et al. 2004. Increased expression of urotensin II and its cognate receptor GPR14 in atherosclerotic lesions of the human aorta. Atherosclerosis, 176:117-23.

Bousette N, Pottinger J, Ramli W, et al. 2006b. Urotensin-II receptor blockade with SB-611812 attenuates cardiac remodelling in experimental ischemic heart disease. Peptides, 27:2919-26.

Charles CJ, Rademaker MT, Richards AM, et al. 2005. Urotensin II: evidence for cardiac, hepatic and renal production. Peptides, 26:2211-14.

Cheung BMY, Leung R, Man YB, et al. 2004. Plasma concentration of urotensin II is raised in hypertension. J Hypertens, 22:1341-4.

Clozel M, Binkert C, Birker-Robaczewska M, et al. 2004. Pharmacology of the urotensin-II receptor antagonist palosuran (ACT-058362; 1-[2(-benzyl-4-hydroxy-piperidin-1-yl)-ethyl]-3-(2-methyl-quinolin-4-yl)urea sulfate salt): First demonstation of a pathophysiological roleof the urotensin system. J Pharmacol Exp Ther, 311:204-12.

Clozel M, Hess P, Qiu C, et al. 2006. The urotensin-II receptor antagonist palosuran improves pancreatic and renal function in diabetic rats. J Pharmacol Exp Ther, 316:1115-21.

Coulouarn Y, Lihrmann I, Jegou S, et al. 1998. Cloning of the cDNA encoding the urotensin II precursor in frog and human reveals intense expression of the urotensin II gene in motoneurons of the spinal cord. Proc Natl Acad Sci USA, 95:15803-8.

Douglas SA, Dhanak D, Johns DG. 2004a. From "gills to pills": urotensin-II as a regulator of mammalian cardiorenal function. Trends Pharmacol Sci, 25:76-85.

Douglas SA, Naselsky D, Ao Z, et al. 2004b. Identification and pharmacological characterization of native, functional human urotensin-II receptors in rhabdomyosarcoma cell lines. Br J Pharmacol, 142:921-32.

Douglas SA, Tayara L, Ohlstein EH, et al. 2002. Congestive heart failure and expression of myocardial urotensin II. Lancet, 359:1990-7.

Dschietzig T, Bartsch C, Pregla R, et al. 2002. Plasma levels and cardiovascular gene expression of urotensin-II in human heart failure. Reg Peptides, 110:33-8.

Dschietzig T, Richter C, Bartsch C, et al. 2001. Flow-induced pressure differentially regulates endothelin-1, urotensin II, adrenomedullin, and relaxin in pulmonary vascular endothelium. Biochem Biophys Res Commun, 289:245-51.

Fontes-Sousa AP, Brás-Silva C, Pires AL, et al. 2007. Urotensin II acutely increases myocardial length and distensibility: potential implications for diastolic function and ventricular remodeling. Naunyn-Schmied Arch Pharmacol, 376:107-15.

Gardiner SM, March JE, Kemp PA, et al. 2006. Regional heterogeneity in the haemodynamic responses to urotensin II infusion in relation to UT receptor localisation. Br J Pharmacol, 147:612-21.

Giebing G, Tölle M, Jürgensen J, et al. 2005. Arrestin-independent internalization and recycling of the urotensin receptor contribute to long-lasting urotensin II-mediated vasoconstriction. Circ Res, 97:707-15.
Gold SJ, Thompson JP, Williams JP, et al. 2007. Does cigarette smoking increase plasma urotensin II concentrations? Eur J Clin Pharmacol, 63:253-7.

Gong H, Wang Y-X, Zhu Y-Z, et al. 2004. Cellular distribution of GPR14 and the positive inotropic role of urotensin II in the myocardium in adult rat. J Appl Physiol, 97:2228-35.

Gray, GA, Jones MR, Sharif I, 2001. Human urotensin II increases coronary perfusion pressure in the isolated rat heart. Potentiation by nitric oxide synthase and cyclooxygenase inhibition. Life Sci, 69:175-80.

Gruson D, Rousseau MF, Ahn SA, et al. 2006. Circulating urotensin II levels in moderate to severe congestive heart failure: its relations with myocardial function and well established neurohormonal markers. Peptides, 27:1527-31.

Hassan GS, Douglas SA, Ohlstein EH, et al. 2005. Expression of urotensin-II in human coronary atherosclerosis. Peptides, 26:2464-72.

Heller J, Schepke M, Neef M, et al. 2002. Increased urotensin II plasma levels in patients with cirrhosis and portal hypertension. $J$ Hepatol, 37:767-72.

Hillier C, Berry C, Petrie MC, et al. 2001. Effects of urotensin II in human arteries and veins of varying calibre. Circulation, 103:1378-81.

Hishikawa K, Nakaki T, Marumo T, et al. 1995. Pressure enhances endothelin-1 release from cultured human endothelial cells. Hypertension, 25:449-452.

Ishihata A, Ogaki T, Aita T, et al. 2005. Role of prostaglandins in urotensin II-induced vasodilation in the coronary arteries of aged rats. Eur $J$ Pharmacol, 523:119-26.

Joyal D, Huynh T, Aiyar N, et al. 2006. Urotensin II levels in acute coronary syndromes. Int J Cardiol, 108:31-5.

Katano Y, Ishihata A, Aita T, et al. 2000. Vasodilator effect of urotensin II, one of the most potent vasoconstricting factors, on rat coronary arteries. Eur J Pharmacol, 402:209-11.

Kemp W, Krum H, Colman J, et al. 2007. Urotensin II: a novel vasoactive mediator linked to chronic liver disease and portal hypertension. Liver Internat, 27:1232-9.

Khan SQ, Bhandari SS, Quinn P, et al. 2007. Urotensin II is raised in acute myocardial infarction and low levels predict risk of adverse clinical outcome in humans. Int $J$ Cardiol, 117:323-8.

Krüger S, Graf J, Kunz D, et al. 2005. Urotensin II in patients with chronic heart failure. Eur J Heart Failure, 7:475-8.

Lacza Z, Busija DW. 2006. Urotensin-II is a nitric oxide-dependent vasodilator in the pial arteries of the newborn pig. Life Sci, 78:2763-6.

Lambert DG. 2007. Urotensin II: from osmoregulation in fish to cardiovascular regulation in man. Br J Anaesthesia, 98:557-9.

Langham RG, Kelly DJ, Gow RM, et al. 2004. Increased expression of urotensin II and urotensin II receptor in human diabetic nephropathy. Am J Kid Dis, 44:826-31.

Lapp H, Boerrigter G, Costello-Boerrigter LC, et al. 2004. Elevated plasma human urotensin-II-like immunoreactivity in ischemic cardiomyopathy. Int J Cardiol, 94:93-7.

Lim M, Honisett S, Sparkes CD, et al. 2004. Differential effect of urotensin II on vascular tone in normal subjects and patients with chronic heart failure. Circulation, 109:1212-4.

MacLean MR, Alexander D, Stirrat A, et al. 2000. Contractile responses to human urotensin-II in rat and human pulmonary arteries: effect of endothelial factors and chronic hypoxia in the rat. Br J Pharmacol, 130:201-4.

Maguire JJ, Kuc RE, Davenport AP. 2000. Orphan-receptor ligand human urotensin II: receptor localization in human tisues and comparison of vasoconstrictor responses with endothelin-1. Br J Pharmacol, 131:441-6.

Maguire JJ, Kuc RE, Wiley KE, et al. 2004. Cellular distribution of immunoreactive urotensin-II in human tissues with evidence of increased expression in atherosclerosis and a greater constrictor response of small compared to large coronary arteries. Peptides, 25:1767-74.

Mallamaci F, Cutrupi S, Pizzini P, et al. 2005. Urotensin II in end-stage renal disease: an inverse correlate of sympathetic function and cardiac natriuretic peptides. J Nephrol, 18:727-32. 
Mallamaci F, Cutrupi S, Pizzini P, et al. 2006. Urotensin II and biomarkers of endothelial activation and atherosclerosis in end-stage renal disease. Am J Hypertens, 19:505-10.

Matsushita M, Shichiri M, Imai T, et al. 2001. Co-expression of urotensin II and its receptor (GPR14) in human cardiovascular and renal tissues. J Hypertens, 19:2185-90.

McDonald J, Batuwangala M, Lambert DG. 2007. Role of urotensin II and its receptor in health and disease. $J$ Anesth, 21:378-89.

Morimoto A, Hasegawa H, Cheng H-J et al. 2002. Urotensin II inhibits left ventricular and myocytes contractile performance and $\left[\mathrm{Ca}^{2+}\right]$ i transient: normal vs CHF. Circulation, 106(Suppl II):II-26.

Mosenkis A, Danoff TM, Aiyar N, et al. 2007. Human urotensin II in the plasma of anephric subjects. Nephrol Dial Transplant, 22:1269-70.

$\mathrm{Ng}$ LL, Loke I, O'Brien RJ, et al. 2002. Plasma urotensin in human systolic heart failure. Circulation, 106:2877-80.

Nothacker H-P, Wang Z, McNeill AM, et al. 1999. Identification of the natural ligand of an orphan G-protein-coupled receptor involved in the regulation of vasoconstriction. Nature Cell Biol, 1:383-5.

Onan D, Pipolo L, Yang E, et al. 2004. Urotensin II promotes hypertrophy of cardiac myocytes via mitogen-activated protein kinases. Mol Endocrinol, 18:2344-54.

Rakowski E, Hassan GS, Dhanak D, et al. 2005. A role for urotensin II in restenosis following balloon angioplasty: use of a selective UT receptor blocker. J Mol Cell Cardiol, 39:785-91.

Richards AM, Nicholls MG, Lainchbury JG, et al. 2002. Plasma urotensin II in heart failure. Lancet, 360:545-6.

Russell FD. 2004. Emerging roles of urotensin-II in cardiovascular disease. Pharmacol Ther, 103:223-43.

Russell FD, Kearns P, Toth I, et al. 2004. Urotensin-II-converting enzyme activity of furin and trypsin in human cells in vitro. J Pharmacol Exp Ther, 310:209-14.

Russell FD, Meyers D, Galbraith AJ, et al. 2003. Elevated plasma levels of human urotensin-II immunoreactivity in congestive heart failure. Am J Physiol Heart Circ Physiol, 285:H1576-81.

Russell FD, Molenaar P. 2004. Investigation of signalling pathways that mediate the inotropic effect of urotensin-II in human heart. Cardiovasc Res, 63:673-81.

Russell FD, Molenaar P, O'Brien DM. 2001. Cardiostimulant effects of urotensin-II in human heart in vitro. Br J Pharmacol, 132:5-9.

Sauzeau V, Le Mellionnec E, Bertoglio J, et al. 2001. Human urotensin IIinduced contraction and arterial smooth muscle cell proliferation are mediated by RhoA and Rho-kinase. Circ Res, 88:1102-4.

Shenouda A, Douglas SA, Ohlstein EH, et al. 2002. Localization of urotensin-II immunoreactivity in normal human kidneys and renal carcinoma. $J$ Histochem Cytochem, 50:885-9.

Sidharta PN, van Giersbergen PLM, Schaarschmidt D, et al. 2005. Multipledose tolerability, safety, pharmacokinetics, and pharmacodynamics of the urotensin-II receptor antagonist palosuran in healthy human subjects. Br J Clin Pharmacol, 60:677-8.

Sidharta PN, Wagner FD, Bohnemeier H, et al. 2006. Pharmacodynamics and pharmacokinetics of the urotensin II receptor antagonist palosuran in macroalbuminuric, diabetic patients. Clin Pharmacol Ther, $80: 246-56$

Sondermeijer B, Kompa A, Komesaroff P, et al. 2005. Effect of exogenous urotensin-II on vascular tone in skin microcirculation of patients with essential hypertension. Am J Hypertens, 18:1195-9.
Stirrat A, Gallagher M, Douglas SA, et al. 2001. Potent vasodilator responses to human urotensin-II in human pulmonary and abdominal resistance arteries. Am J Physiol Heart Circ Physiol, 280:H925-8.

Sugo T, Murakami Y, Shimomura Y, et al. 2003. Identification of urotensin II-related peptide as the urotensin II-immunoreactive molecule in the rat brain. Biochem Biophys Res Commun, 310:860-8.

Suguro T, Watanabe T, Ban Y, et al. 2007. Increased human urotensin II levels are correlated with carotid atherosclerosis in essential hypertension. Am J Hypertens, 20:211-17.

Takahashi K, Totsune K, Murakami O, et al. 2001. Expression of urotensin II and urotensin II receptor mRNAs in various human tumor cell lines and secretion of urotensin II-like immunoreactivity by SW-13 adrenocortical carcinoma cells. Peptides, 22:1175-9.

Thompson JP, Watt P, Sanghavi S, et al. 2003. A comparison of cerebrospinal fluid and plasma urotensin II concentrations in normotensive and hypertensive patients undergoing urological surgery during spinal anesthesia: a pilot study. Anesth Analg, 97:1501-3.

Totsune K, Takahashi K, Arihara Z, et al. 2001. Role of urotensin II in patients on dialysis. Lancet, 358:810-11.

Totsune K, Takahashi K, Arihara Z, et al. 2003. Increased plasma urotensin II levels in patients with diabetes mellitus. Clin Sci, 104:1-5.

Tsutamoto T, Wada A, Maeda Y, et al. 1994. Relation between endothelin-1 spillover in the lungs and pulmonary vascular resistance in patients with chronic heart failure. J Am Coll Cardiol, 23:1427-33.

Tzanidis A, Hannan RD, Thomas WG, et al. 2003. Direct actions of urotensin II on the heart. Implications for cardiac fibrosis and hypertrophy. Circ Res, 93:246-53.

Wagner OF, Christ G, Wojta J, et al. 1992. Polar secretion of endothelin-1 by cultured endothelial cells. $J$ Biol Chem, 267:16066-8.

Wang D, Iversen J, Wilcox CS, et al. 2003. Endothelial dysfunction and reduced nitric oxide in resistance arteries in autosomal-dominant polycystic kidney disease. Kid Internat, 64:1381-8.

Watanabe T, Kanome T, Miyazaki A, et al. 2006b. Human urotensin II as a link between hypertension and coronary artery disease. Hypertens Res, 29:375-87.

Watanabe T, Takahashi K, Kanome T et al. 2006a. Human urotensin-II potentiates the mitogenic effect of mildly oxidized low-density lipoprotein on vascular smooth muscle cells: comparison with other vasoactive agents and hydrogen peroxide. Hypertens Res, 29:821-31.

Wilkinson IB, Affolter JT, de Haas SL, et al. 2002. High plasma concentrations of human urotensin II do not alter local or systemic hemodynamics in man. Cardiovasc Res, 53:341-7.

Yoshimoto S, Ishizaki Y, Sasaki T, et al. 1991. Effect of carbon dioxide and oxygen on endothelin production by cultured porcine cerebral endothelial cells. Stroke, 22:378-83.

Zhang AY, Chen Y-F, Zhang DX, et al. 2003. Urotensin II is a nitric oxide-dependent vasodilator and natriuretic peptide in the rat kidney. Am J Physiol Renal Physiol, 285:F792-8.

Zhang Y-G, Li Y-G, Liu B-G, et al. 2007. Urotensin II accelerates cardiac fibrosis and hypertrophy of rats induced by isoproterenol. Acta Pharmacol Sin, 28:36-43.

Zhu Y-C, Zhu Y-Z, Moore PK. 2006. The role of urotensin II in cardiovascular and renal physiology and diseases. Br J Pharmacol, 148:884-901.

Zoccali C, Mallamaci F, Tripepi G, et al. 2006. Urotensin II is an inverse predictor of incident cardiovascular events in end-stage renal disease. Kidney Int, 69:1253-8. 
